https://helda.helsinki.fi

Taxonomic revision of two Iranian Arenaria endemics reveals further synonyms in Eremogone (Caryophyllaceae)

Sennikov, Alexander N.

$2020-10$

Sennikov , A N \& Lazkov , G A 2020 , ' Taxonomic revision of two Iranian Arenaria endemics reveals further synonyms in Eremogone (Caryophyllaceae) ', Annales Botanici Fennici, vol. 57 , no. 4-6 , pp. 223-226 . https://doi.org/10.5735/085.057.0405

http://hdl.handle.net/10138/323390

https://doi.org/10.5735/085.057.0405

publishedVersion

Downloaded from Helda, University of Helsinki institutional repository.

This is an electronic reprint of the original article.

This reprint may differ from the original in pagination and typographic detail.

Please cite the original version. 


\title{
Taxonomic Revision of Two Iranian Arenaria Endemics Reveals Further Synonyms in Eremogone (Caryophyllaceae)
}

\author{
Authors: Sennikov, Alexander N., and Lazkov, Georgy A.
}

Source: Annales Botanici Fennici, 57(4-6) : 223-226

Published By: Finnish Zoological and Botanical Publishing Board URL: https://doi.org/10.5735/085.057.0405

BioOne Complete (complete.BioOne.org) is a full-text database of 200 subscribed and open-access titles in the biological, ecological, and environmental sciences published by nonprofit societies, associations, museums, institutions, and presses.

Your use of this PDF, the BioOne Complete website, and all posted and associated content indicates your acceptance of BioOne's Terms of Use, available at www.bioone.org/terms-of-use.

Usage of BioOne Complete content is strictly limited to personal, educational, and non - commercial use. Commercial inquiries or rights and permissions requests should be directed to the individual publisher as copyright holder.

BioOne sees sustainable scholarly publishing as an inherently collaborative enterprise connecting authors, nonprofit publishers, academic institutions, research libraries, and research funders in the common goal of maximizing access to critical research. 


\title{
Taxonomic revision of two Iranian Arenaria endemics reveals further synonyms in Eremogone (Caryophyllaceae)
}

\author{
Alexander N. Sennikov ${ }^{1,2, \star}$ \& Georgy A. Lazkov ${ }^{3}$ \\ 1) Botanical Museum, Finnish Museum of Natural History, P.O. Box 7, Fl-00014 University of \\ Helsinki, Finland (“corresponding author's e-mail: alexander.sennikov@helsinki.fi) \\ 2) Herbarium, Komarov Botanical Institute of Russian Academy of Sciences, Prof. Popov Str. 2, \\ RU-197376 St. Petersburg, Russia \\ 3) Laboratory of Flora, Institute of Biology, Kyrgyz Academy of Sciences, 720071 Bishkek, Kyrgyz \\ Republic
}

Received 20 Apr. 2020, final version received 1 June 2020, accepted 1 June 2020

Sennikov A.N. \& Lazkov G.A. 2020: Taxonomic revision of two Iranian Arenaria endemics reveals further synonyms in Eremogone (Caryophyllaceae). - Ann. Bot. Fennici 57: 223-226.

Two recently described endemics of northern Iran are reduced to synonyms: Arenaria assadii to a synonym of Eremogone brachypetala, and A. longibracteata to a synonym of E. macrantha. Both species were already known from the same places in Iran but were overlooked in the latest treatments. Nomenclatural data are verified and corrected for all the taxa involved.

Phylogenetic studies have recently confirmed the generic status of Eremogone (Caryophyllaceae), which was resolved outside Arenaria and placed in a separate tribe, Eremogoneae (Harbaugh et al. 2010, Sadeghian et al. 2015). Following the dismemberment of Arenaria s. lato, a number of new combinations in Eremogone for species described from the Old World have been provided (Rabeler \& Wagner 2015).

Iran is a recognised centre of the global diversity of vascular plants, with a total of 2597 (sub)endemic species documented (Noroozi et al. 2019). Among these endemics, three species recently described under Arenaria (Fadaie et al. 2010, Fadaie 2013) are actually referable to Eremogone. Intentionally or not, these species were omitted from the list of Rabeler and Wagner (2015). One of those presumed local endemics, A. kandavanensis from northern Iran was recently reduced to a synonym of Eremogone fursei by Lazkov and Sennikov (2020).

Two further local endemics, $A$. assadii and $A$. longibracteata, described in Arenaria by Fadaie (2013) but belonging in Eremogone, are evaluated in this study in order to contribute to the revision of the latter genus.

The protologues of $A$. assadii and A. longibracteata (Fadaie 2013) were examined and compared with previous treatments and revisions of Arenaria s. lato in Iran and the Caucasus (Schischkin \& Knorring 1936, McNeill 1967, Popova 1972, Rechinger 1988, Nersesian 2004, Lazkov 2012). Type specimens were examined de visu or from scanned images (available at JSTOR Global Plants) or photographs. Diagnostic characters were evaluated on the basis of published treatments and our revision of herbarium material from Iran and the Caucasus at LE. 
We compared the presumed endemics $A$. assadii and A. longibracteata (Fadaie 2013) with taxa occurring in the Caucasus (Lazkov 2012). That comparison revealed that these species have long been known from the same places in Iran under other names.

\section{Eremogone brachypetala (Grossh.) Czerep.}

Sosud. Rast. SSSR: 160. 1981. - Arenaria graminea var. brachypetala Grossh., Beih. Bot. Centralbl. 44(Abt. 2): 209. 1927. - Arenaria brachypetala (Grossh.) T.N. Popova, Novosti Sist. Vyssh. Rast. 9: 160. 1972. — TyPE: Iran. East Azerbaijan: "Prope Tebriz, in lapidosis, 1500 m", 25 June 1924 A. Grossheim [Grossheim \& Schischkin, Plantae orientales exsiccatae no. 278] (lectotype LE!, designated by Popova (1972: 160); isotypes LE!, K barcode K000723968 photo!, TBI barcodes TBI1024893 and TBI1024894 photo!, TGM).

Arenaria assadii Fadaie, Iran. J. Bot. 19(1): 35. 2013, syn. nov. - TYPE: Iran. West Azerbaijan: Khoy, $1300 \mathrm{~m}$ a.s.1., 28 June 2003 M. Assadi 85212 (holotype TARI, photo!).

Arenaria assadii was described as a relative of A. blepharophylla (=Eremogone blepharophylla), from which it was said to differ in longer sepals (4-5 mm long) and petals that are shorter than sepals (Fadaie 2013). These characters perfectly match Eremogone brachypetala (syn. Arenaria brachypetala) (Popova 1972), which was described from the same area in Iran (Iranian Azerbaijan) but neglected by Rechinger (1988) and Fadaie (2013). The distribution of this species extends from southern Armenia and Nakhchivan Autonomous Republic of Azerbaijan to Iranian Azerbaijan (Popova 1972, Nersesian 2004, Lazkov 2012).

The plants of $A$. graminea with shorter petals had been originally described as a variety (Grossheim 1927, Lazkov 2002), which was later elevated to the level of species (Popova 1972, Czerepanov 1981, Lazkov 2012). Eremogone brachypetala is indeed most closely related to E. graminea, from which it differs mainly in the petals being half as long as or nearly reaching the length of sepals (vs. 1.5 times longer than sepals) and a compact inflorescence with shorter pedicels (Popova 1972, Nersesian 2004). Their distributions do not overlap (Nersesian 2004).

In Iran, E. brachypetala is known from two localities. The type locality is situated near
Tebriz in East Azerbaijan. The second locality at Khoy in West Azerbaijan, from which $A$. assadii was described, seems to coincide with the place where the oldest specimen was collected ("Tshilachana" Mts. [Chelleh Khaneh = Çillə Xana Dağ $1,15 \mathrm{~km}$ N of Khoy, at $38.68^{\circ} \mathrm{N}$, $45.00^{\circ} \mathrm{E}$ ], 31 May $1828 \mathrm{~J}$. Szovits (LE); Nerse$\operatorname{sian} 2004)$.

\section{Eremogone macrantha (McNeill) Ikonn.}

Novosti Sist. Vyssh. Rast. 10: 138. 1973. - Arenaria macrantha Schischk., Fl. USSR 6: 886. 1936, nom. illeg., non (Rydb.) Nelson 1909. - Arenaria holostea subsp. macrantha McNeill, Notes Roy. Bot. Gard. Edinburgh 24(3): 297. 1963. - TypE: Turkey. Iğdır: "Takjaltu” [Takeltu], 10 June 1913 Yu. Woronow 12254 (holotype LE!).

Arenaria longibracteata Fadaie, Iran. J. Bot. 19(1): 35. 2013, syn. nov. - TYPE: Iran. West Azerbaijan: road Shahpur to Rezaiyeh, Ghoushi pass, 1750 m a.s.1., 21 May 1976 H. Runemark \& H. Foroughi 19588 (holotype TARI, photo!).

Fadaie (2013) distinguished $A$. longibracteata from A. szowitsii by longer cauline leaves (5.5-

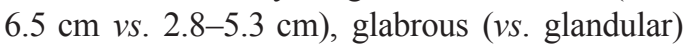
pedicels, much longer floral bracts $(7-7.5 \mathrm{~mm} v \mathrm{~s}$. $2.5-4.5 \mathrm{~mm}$ ), and typically longer sepals. These characters exactly point at Eremogone macrantha (Popova 1972), which has larger flowers and remarkably long floral bracts, easily distinguishing this species among the relatives.

Eremogone macrantha had already been reported from Iranian Azerbaijan (as Arenaria holostea subsp. macrantha) from the same area as the type locality of $A$. longibracteata (Rechinger 1988), but it was treated as $A$. holostea by Fadaie (2013). The affinity of $A$. longibracteata with $E$. macrantha rather than E. szowitsii can be seen in the basal parts of the plant: A. longibracteata and $E$. macrantha have a thick caudex, with several stems coming from a rootstock, whereas E. szowitsii has thin, branched rhizomes with few sparsely situated stems (Popova 1972).

Eremogone macrantha was originally characterised by basally pubescent stems, as opposed to the glabrous stems of E. holostea (Schischkin \& Knorring 1936, Rechinger 1988). The stems of $A$. longibracteata are glabrous (Fadaie 2013). This character is unstable and may vary in E. macrantha, which consistently differs from $E$. holostea in longer sepals $(8-11 \mathrm{~mm}$ vs. $6.5-8 \mathrm{~mm})$ and 
petals (10-14 mm vs. 8-10 mm) (Popova 1972). The dimensions of flower parts in A. longibracteata and E. macrantha closely coincide; the sepals in A. longibracteata are $8-10 \mathrm{~mm}$ long and the petals are 10-12 mm long (Fadaie 2013).

The illustration in the protologue of $A$. longibracteata, showing a plant with numerous long non-flowering shoots, is at odds with the life form in Eremogone. The presumed sterile shoots in the illustration are actually generative shoots, which are developing stems yet without flowers. Thickened upper parts of these shoots indicate that the absence of flowers could be due to insect damage; otherwise, the shoots in Eremogone develop simultaneously and do not follow each other with a delay.

Eremogone macrantha is distributed in the South Caucasus, namely in Azerbaijan, Armenia, Turkey and Iran (McNeill 1967, Rechinger 1988, Lazkov 2012). Its type locality (Takeltu; $39.746^{\circ} \mathrm{N}, 44.438^{\circ} \mathrm{E}$ ) is situated on the eastern side of Mount Ararat in Turkey, at a distance of $5 \mathrm{~km}$ from the border with Iran. Eremogone holostea, the small-flowered counterpart of $E$. macrantha, is distributed in the North Caucasus (Lazkov 2012).

The authorship of the name E. macrantha is commonly cited as "(Schischk.) Ikonn." That citation is incorrect because Schischkin (Schischkin \& Knorring 1936) published an illegitimate later homonym. The first legitimate name for this taxon, provided by McNeill (1963), should be treated as a basionym for all further nomenclatural transfers.

\section{Conclusions}

This study highlights the importance of comprehensive inventories which should include all literature published in the country under study and in all neighbouring countries, ideally leading to a global database. In the case of Iranian Eremogone, such omissions and oversights included taxa that have been already reported or even described from the country; these omissions led to superfluous descriptions of "new local endemics" of Iran.

Besides producing "taxonomic noise", superfluous descriptions of non-existent endemics may potentially obscure or even alter the picture of real endemism and biodiversity hotspots. Noroozi et al. (2019) concluded that the Azerbaijan Plateau, which harbours both "Arenaria assadii" and "A. longibracteata", is a national biodiversity hotspot which includes $21 \%$ of Iranian vascular plant endemics, half of which are endemic to this area. Nevertheless, the flora of the Azerbaijan Plateau is largely shared with eastern Turkey, Transcaucasia and the Caucasus (Noroozi et al. 2019), where Eremogone brachypetala and E. macrantha actually occur. Further studies may increase this share and correspondingly decrease the number of plant endemics in the Iranian Azerbaijan Plateau.

\section{Acknowledgements}

Our sincere thanks go to an anonymous reviewer of our earlier paper for his kind suggestions that triggered this little study.

\section{References}

Czerepanov S.K. [Черепанов, С.K.] 1981: [Vascular plants of the USSR.] — Science Publishers, Leningrad. [In Russian].

Fadaie F. 2013: Three new species and a key to the species of the genus Arenaria (Caryophyllaceae) in Iran. - Iranian Journal of Botany 19: 32-39.

Fadaie F., Sheidai M. \& Assadi M. 2010: A new species of the genus Arenaria (Caryophyllaceae) from Iran. - Iranian Journal of Botany 16: 218-220.

Grossheim A.A. 1927: Iter persicum primum. - Beihefte zum Botanischen Centralblatt 44(2): 199-247.

Harbaugh D.T., Nepokroeff M., Rabeler R.K., McNeill J., Zimmer E.A. \& Wagner W.L. 2010: A new lineage-based tribal classification of the family Caryophyllaceae. International Journal of Plant Sciences 171: 185-198.

Lazkov G.A. [Лазьков Г.А.] 2002: Arenaria graminea C.A. Mey. - In: Konechnaya G.Yu. [Конечная Г.Ю.] (ed.), Schedae ad Herbarium Florae Rossicae et civitatum collimitanearum ab Instituto Botanico Academiae Scientiarum Rossicae editum 29: 54-55. [In Russian].

Lazkov G.A. [Лазьков Г.А.] 2012: Arenaria L. - In: Takhtajan A.L. [Тахтаджян А.Л.] (ed.), Conspectus florae Caucasi, vol. 3(2): 147-150. KMK Scientific Press, Saint-Petersburg \& Moscow. [In Russian].

Lazkov G.A. \& Sennikov A.N. 2020: Arenaria kandavanensis is a synonym of A. fursei and belongs in Eremogone (Caryophyllaceae). - Annales Botanici Fennici 57: 185-190.

McNeill J. 1963: Taxonomic studies in the Alsinoideae, II. A revision of the species in the Orient. - Notes from the Royal Botanical Garden Edinburgh 24: 241-426. 
McNeill J. 1967: Arenaria L. — In: Davis P.H. (ed.), Flora of Turkey and the East Aegean Islands, vol. 2: 17-38. Edinburgh University Press, Edinburgh.

Nersesian A.A. 2004: Notes on Arenaria brachypetala (Grossh.) T.N. Popova (Caryophyllaceae). - Flora, Rastitel'nost' i Rastitel'nye Resursy Armenii 15: 33-36.

Noroozi J., Talebi A., Doostmohammadi M., Manafzadeh S., Asgarpour Z. \& Schneeweiss G.M. 2019: Endemic diversity and distribution of the Iranian vascular flora across phytogeographical regions, biodiversity hotspots and areas of endemism. - Scientific Reports 9: 12991, https://doi.org/10.1038/s41598-019-49417-1.

Popova T.N. [Попова T.H.] 1972: [Notes on some Caucasian species of Caryophyllaceae]. - Novosti Sistematiki Vysshikh Rastenii 9: 159-162. [In Russian].

Rabeler R.K. \& Wagner W.L. 2015: Eremogone (Caryophyl- laceae): new combinations for Old World species. PhytoKeys 50: 35-42.

Rechinger K.H. 1988: Arenaria L. - In: Rechinger K.H. (ed.), Flora Iranica, vol. 163: 6-28. Akademische Druck- und Verlaganstalt, Graz.

Sadeghian S., Zarre S., Rabeler R.K. \& Heubl G. 2015: Molecular phylogenetic analysis of Arenaria (Caryophyllaceae: tribe Arenarieae) and its allies inferred from nuclear DNA internal transcribed spacer and plastid DNA rps16 sequences. - Botanical Journal of the Linnean Society 178: 648-669.

Schischkin B.K. \& Knorring O.Е. [Шишкин Б.К. \& Кнорринг О.Э.] 1936: Arenaria L. — In: Schischkin B.К. [Шишкин Б.К.] (ed.), [Flora of the USSR], vol. 6: 517-539. Academy of Sciences of the USSR, Moscow \& Leningrad. [In Russian]. 